Journal of Epidemiology and Public Health (2016), 1(3): 164-174

https://doi.org/10.26911/jepublichealth.2016.01.03.03

\title{
The Relationship Between HIV Incidence Rate, District/ Municipality Health Budget, Healthy House Rate, and Tuberculosis Prevalence in Indonesia
}

\author{
Balgis'), Panji Fortuna H²), Lukman Hifli²) \\ 1)Department of Public Health, Faculty of Medicine, Universitas Sebelas Maret \\ 2)Department of Public Health, Faculty of Medicine, Universitas Padjajaran
}

\begin{abstract}
Background: Tuberculosis (TB) remains an important public health concern in the world including Indonesia. This study aimed to estimate the relationship between HIV incidence rate, district/ municipality health budget, healthy house rate, and tuberculosis prevalence in Indonesia.

Subjects and Method: This was an analytic and observational study with ecologic study design. The data were obtained from 33 provinces, 497 districts/ municipalities that were collected by Basic Health Research (Riset Kesehatan Dasar/Riskesdas) 2013. The dependent variable was TB prevalence. The independent variables were HIV incidence rate, district/ municipality health budget, and healthy house rate. TB diagnosis was made by health personnel using sputum examination, chest X-ray photo, or both. The data were analyzed by multiple linear regression.

Results: District/ municipality budget $(b=-14.07 ; 95 \% \mathrm{CI}=-24.09$ to $-4.05, \mathrm{p}=0.080)$, and healthy house rate $(\mathrm{b}=-3.62 ; 95 \% \mathrm{CI}=-6.28$ to $-0.96 ; \mathrm{p}=0.009)$ decreased TB prevalence. HIV incidence rate $(b=0.05,95 \% \mathrm{CI}=0.02$ to $0.08, \mathrm{p}=0.002)$ increased $\mathrm{TB}$ prevalence. $\mathrm{R}^{2}$ was $56.5 \%$ for this linear regression model, and the overall model was statistically significant $(\mathrm{p}=0.001)$.

Conclusion: District/ municipality budget, healthy house rate, and HIV incidence rate are related with TB prevalence.
\end{abstract}

Keywords: district/ municipality budget, healthy house rate, HIV incidence rate, TB prevalence

\section{Correspondence:}

Balgis. Department of Public Health, Faculty of Medicine, Universitas Sebelas Maret, Surakarta, Central Java.

\section{BACKGROUND}

Tuberculosis (TB) is a direct infectious disease caused by Mycobacterium tuberculosis bacteria (Suriadi, 2001). Most TB germs attack the lung parenchyma and cause pulmonary tuberculosis, but can also attack other body organs (extra-pulmonary TB) such as the pleura, lymph nodes, bones, and other extra-lung organs (Aditama, 2008).

TB still remains an important public health concern in the world including Indonesia that causing health problems for millions of people per year. Tuberculosis is ranked second as the main cause of death from infectious diseases in the world after HIV.

Based on World Health Organization (WHO) data in 2014, the number of world population infected with TB germs in 2013 was 9 million people, while in 2014 there were 9.6 million people. The largest number of people infected with TB is in Africa (37\%), Southeast Asia (28\%), and in the Eastern Mediterranean (17\%) (WHO, 2015).

According to the results of the 2016 National TB Prevalence Survey, Indonesia ranks second in the countries with the highest TB burden in the world. The estimated TB prevalence for all cases is 660,000 and the estimated incidence is 
430,000 new cases per year (WHO, 2010a). The number of deaths due to $\mathrm{TB}$ is estimated at 61,000 deaths happened per year. Tuberculosis, along with malaria and HIV/AIDS, is one of the diseases that its control has become a global commitment in the Millennium Development Goals (MDGs) (Kementerian Kesehatan Republik Indonesia, 2011).

The prevalence of pulmonary TB in Indonesia is grouped into three regions, namely Sumatra (33\%), Java and Bali (23\%), and Eastern Indonesia (44\%) (Kementerian Kesehatan Republik Indonesia, 2008).

TB case finding rates in Indonesia amounted to $78.30 \%$ in 2010 and $83.5 \%$ in 2011. In 2012 there was a decrease in TB cases to $82.4 \%$, and $38.4 \%$ (quarterly 2 data) in 2013 (Kementerian Kesehatan Republik Indonesia, 2013a).

The prevalence of Indonesian population diagnosed with pulmonary $\mathrm{TB}$ by health workers in 2013 was $0.4 \%$. The seven provinces with the highest pulmonary TB in Indonesia are West Java (0.7\%), Papua (0.6\%), DKI (0.6\%), Gorontalo (0.5\%), Banten (0.4\%), West Papua (0.4\%), and Central Java (0.4\%) (Kementerian Kesehatan Republik Indonesia, 2013b).

The implementation of TB control programs at the national level shows positive progress in case detection and TB treatment success, but there are still gaps. Based on achievements in 2010, 25 provinces in Indonesia had not reached the target of $70 \%$ and only 8 provinces had been able to reach the target of $70 \%$ with $85 \%$ treatment success (Kementerian Kesehatan Republik Indonesia, 2010).

There are differences in the prevalence of pulmonary TB in each province in Indonesia. This difference is allegedly due to several factors including demography, sociology, economics, culture, personal, education, psychology, geography, and inadequate political commitment, inadequate health care facilities, the number and distribution of health workers that are not evenly distributed, and funding systems that still not optimal. In addition, there are several other factors that also have influence, including endemic Human Immunodeficiency Virus (HIV) infection, and the condition of a slum home environment (WHO, 2010b; Riskesdas, 2013).

The number and even distribution of Health Center that are still not balanced with the population, As well as, the number, type, and distribution of health workers in all parts of Indonesia that are still not evenly distributed can be a factor that is still not optimal for TB control in Indonesia. Determination of budget for TB control and the budget available is also a constraint in every province (Kementerian Kesehatan Republik Indonesia, 2016).

In addition, what should also be a concern in this TB control effort is endemic HIV infection. Based on data from the Indonesian Ministry of Health that in 2013 new HIV positive cases had increased by $35 \%$ compared to 2012. The occurrence of an increase in HIV infection has led to changes in the epidemiology of tuberculosis. HIV has transformed tuberculosis from an endemic disease into an epidemic disease throughout the world (Suharyo, 2013).

The physical condition of a house that does not meet the criteria of a healthy house according to the requirements of the Ministry of Health and unhealthy location of residence or slum can be the cause of easy transmission of TB disease (Riskesdas, 2013).

The health system that has been formulated by the government also has an important role in TB control and TB control management, and is likely to be one of the 
Journal of Epidemiology and Public Health (2016), 1(3): 164-174

https://doi.org/10.26911/jepublichealth.2016.01.03.03

factors causing the emergence of TB prevalence in various provinces in Indonesia, so that research needs to be done to assess and analyze whether differences in health systems can affect TB prevalence in various provinces in Indonesia.

According to WHO, the health system is influenced by six core components consisting of: 1) Health services, 2) Health care, 3) Health information systems, 4) Access to essential treatment, 5) Finance, 6) Leadership (Helper and Sahat, 2010).

This study aimed to analyze the relationship between health systems (health care facilities, health workers, finance), and risk factors that influence TB transmission, namely HIV infection, healthy houses and neighborhoods (slum environments) with TB prevalence in various provinces in Indonesia.

The number and distribution of health service facilities and health workers that were not evenly distributed in each province and municipality budget or inadequate costs can be factors that causing the slow handling of TB cases. In addition to the increasing cases of HIV infection, there were still many unhealthy physical conditions of houses and there were still many people living in slums, a risk factor for the easy and fast transmission of TB infection. So it was necessary to do a study to see how far the health system factors and risk factors for $\mathrm{TB}$ were influential in $\mathrm{TB}$ prevention efforts in Indonesia.

The writer hopes that this study will be useful for all parties involved in TB control efforts to be able to determine plans and strategies to achieve goals.

\footnotetext{
SUBJECTS AND METHOD

1. Study design

This was an analytic and observational study with a cross sectional approach using secondary data derived from Basic Health
}

Research (Riskesdas) data and Indonesia's health profile in 2013.

\section{Population and sample}

The population and sample of this study were population and samples from Riskesdas 2013. Samples used in this study were all samples from 33 provinces, 497 districts/cities used as samples of households and household members from Riskesdas data in 2013.

\section{Study variabel}

The dependent variable was pulmonary TB prevalence in 33 provinces in Indonesia. While the independent variables were the health system (health services, health workers, health budget) and risk factors for pulmonary tuberculosis (new cases of HIV healthy house and slum dwellings).

\section{Data analysis}

Descriptive data analysis was carried out to describe the study variables of pulmonary TB prevalence in 33 provinces in Indonesia, the number of health centers and their ratio to population, the number of doctors per 100,000 population, district/municipality budget, the number of new cases of HIV, healthy houses and slums in the form of frequency distribution, flat, standard deviation, and range. Linear regression analysis and multiple linear regression analysis were performed.

\begin{tabular}{l}
\hline RESULTS \\
The prevalence of pulmonary TB in various \\
provinces in Indonesia varies with the \\
lowest prevalence in Bali, Lampung and \\
Riau that was 100 per 100,00o population \\
and the highest prevalence in West Java \\
was 700 per 100,000 population followed \\
by the Special Capital Region of Jakarta \\
was 600 per 100,000 population. The \\
average prevalence of pulmonary TB (SB) \\
in Indonesia was 290,909 people per \\
100,000 population.
\end{tabular}


Based on the number of Health Center in various provinces, the lowest ratio of Health Center per 10,000 population was 1.80 in Banten and the highest was 15.21 in West Papua. The average number of doctors and nurses per 100,000 population was 201.6. Four provinces had the highest number of doctors and nurses of more than 300 per 100,000 population; DKI Jakarta 349.60, West Papua 342.80, North Sulawesi 323.00 and Maluku 318.80. Whereas the provinces that only had less than 110 doctors and nurses were West Java 101.30, Lampung 105.3 and Bali 107.5. The average municipality budget according to health functions in percentage in 33 provinces in Indonesia varies from 1.95 in Papua Province to 15.95 in the province of South Kalimantan.

The average of new HIV cases were 880.22 with the highest number of new cases founded in Special Capital Region of Jakarta as many as 5,865, while in West Sulawesi there were no new cases of HIV. Based on the ratio of houses that belong to the category of healthy houses, only six provinces had healthy category of houses of more than $75 \%$ including Bali, Central Sulawesi, South Sulawesi, West Sulawesi and North Maluku. Four provinces had less than 50\% of healthy houses. They were Maluku, Papua, Aceh and South Kalimantan. Provinces with the location of houses in the slums area of more than 25\% were Special Capital Region of Jakarta, West Java, South Kalimantan and the islands of Riau.

The description of the health system and risk factors for pulmonary TB with the prevalence (frequency distribution) of pulmonary $\mathrm{TB}$ in 33 provinces in Indonesia can be seen in Table 1 .

Table 1 showed that the pulmonary TB prevalence was decreasing with the increase in the municipality budget of the Government Province according to the health function, as well as the increasing number of healthy houses. While the increase in the number of new cases of HIV, as well as an increase in the number of houses in the slum environment had an effect on increasing the prevalence of pulmonary TB. Meanwhile, the number of health centers, doctors and nurses did not affect the prevalence of pulmonary TB.

Univariable and multivariable analyze were carried out using linear regression test to determine the relationship between health systems and risk factors for pulmonary tuberculosis with the pulmonary $\mathrm{TB}$ prevalence in 33 provinces in Indonesia, The results of the logistic regression test analysis were listed in Table 2 below. In the model, there were three independent variables, namely municipality budget, number of new cases of HIV, and healthy houses that had a statistically significant relationship with TB prevalence.

Table 1. Frequency distribution of pulmonary tuberculosis prevalence, health systems and pulmonary TB risk factors in 33 provinces in Indonesia

\begin{tabular}{lll}
\hline \multicolumn{1}{c}{ Characteristic } & \multicolumn{1}{c}{ Mean (SD) } & \multicolumn{1}{c}{ Range } \\
\hline Pulmonary TB Prevalence (per 100,000 population) & $290.909(142.221)$ & 100.00 to 700.00 \\
Number of Health Center (per 100,000 population) & $5.55(3.12)$ & 1.80 to 15.21 \\
$\begin{array}{l}\text { Number of doctors and nurses (per 100,000 } \\
\text { population) }\end{array}$ & $201.60(72.32)$ & 101.30 to 349.60 \\
District/municipality health budget (\%) & $7.79(3.40)$ & 1.95 to 15.95 \\
Number of new cases of HIV & $880.22(1364.49)$ & 5865.00 to $<0.01$ \\
Number of healthy houses & $66.735(13.04)$ & 33.05 to 88.12 \\
Location of houses in slums & $16.16(5.925)$ & 29.40 to 6.90 \\
\hline
\end{tabular}


Journal of Epidemiology and Public Health (2016), 1(3): 164-174

https://doi.org/10.26911/jepublichealth.2016.01.03.03
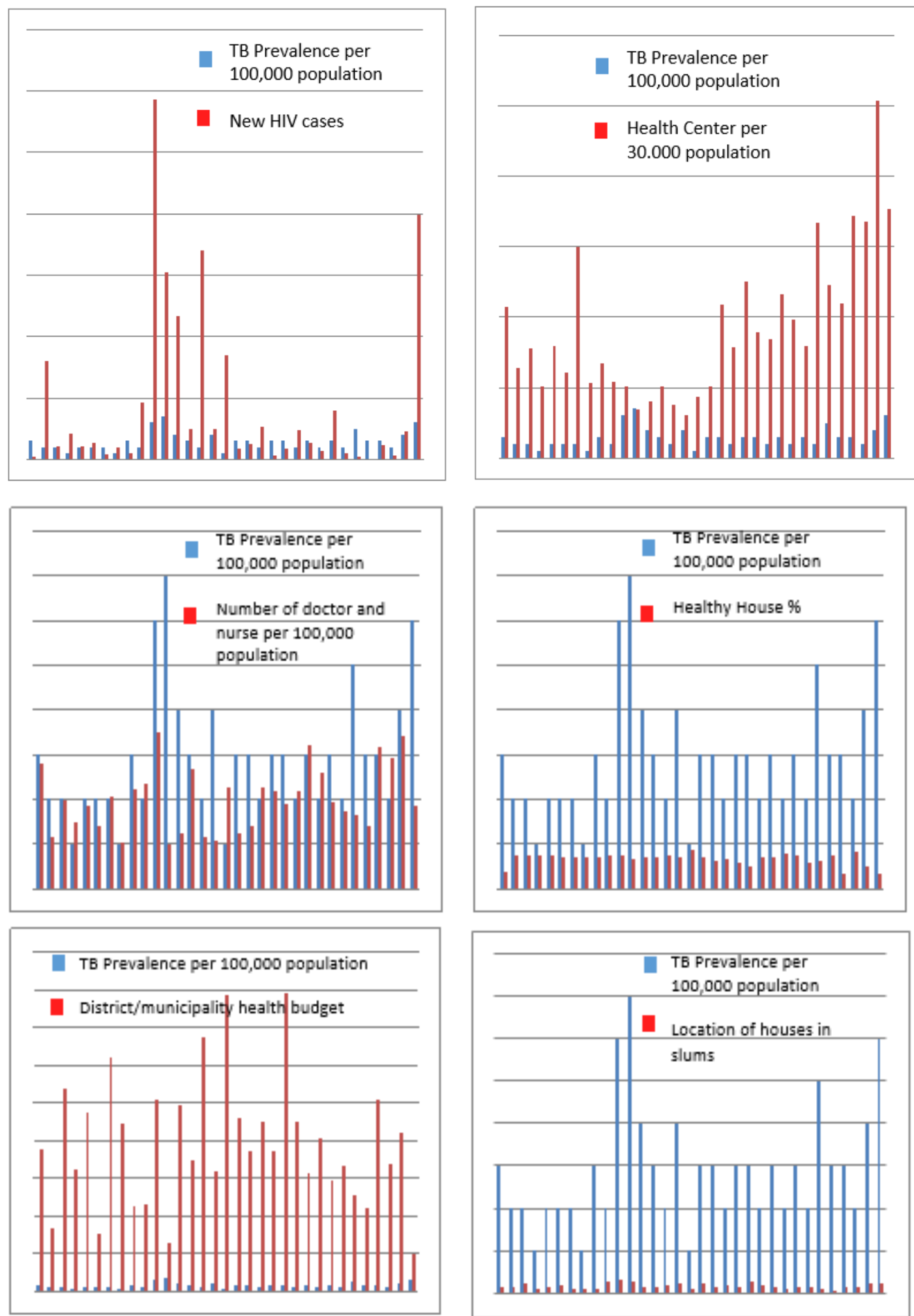

Figure 1. Relationship between health systems, TB risk factors with pulmonary TB prevalence

In each percent increase in municipality budget, the pulmonary $\mathrm{TB}$ prevalence fell by $14.07 \%(95 \% \mathrm{CI}=-35.22$ to $-4.05 ; p=0.08)$. Every increase in new 
cases of HIV would be followed by an increase in TB prevalence of 0.48 (95\% CI= 019 to $076 ; p=0.002)$. Every percent increase in the number of healthy houses would reduce the pulmonary TB prevalence by $3.62 \%$ ( $95 \% \mathrm{CI}=-6,275$ to $-0,956 ; \mathrm{p}=$
0.009). The results of $\mathrm{R}^{2}$ in the multiple linear regression test of the three variables meant that the three variables explained $56.5 \%$ of all factors that affected the prevalence of pulmonary $\mathrm{TB}$ in Indonesia and were statistically significant $(\mathrm{p}=0.001)$.

Table 2. The results of multiple linear and linear regression analysis between health systems and risk factors for pulmonary TB with the pulmonary TB prevalence in 33 provinces in Indonesia

\begin{tabular}{|c|c|c|c|c|}
\hline Variable & $\begin{array}{c}\text { Linier } \\
\text { Regression } \\
\beta(95 \% \text { CI) } \\
\end{array}$ & $\mathbf{p}$ & $\begin{array}{c}\text { Multiple Linear } \\
\text { Regression } \\
\beta(95 \% \text { CI }) \\
\end{array}$ & $\mathbf{p}$ \\
\hline $\begin{array}{l}\text { Number of Health Center } \\
\text { (per 100,000 population) }\end{array}$ & $\begin{array}{c}4.920(-11.74 \text { to }- \\
21.58)\end{array}$ & 0.551 & \#\#\# & \\
\hline $\begin{array}{l}\text { Number of doctors and } \\
\text { nurses } \\
\text { (per 100,000 population) }\end{array}$ & $\begin{array}{c}0.108(-0.61 \text { to }- \\
0.083)\end{array}$ & 0.76 & \#\#\# & \\
\hline $\begin{array}{l}\text { District/municipality } \\
\text { health budget (\%) }\end{array}$ & $\begin{array}{c}-14.56(-35.22 \text { to } \\
64.74)\end{array}$ & 0.047 & $\begin{array}{c}-14.07(-24.086 \text { to }- \\
4.053)\end{array}$ & 0.008 \\
\hline $\begin{array}{l}\text { Number of new cases of } \\
\text { HIV }\end{array}$ & $\begin{array}{c}0.059(0.27 \text { to } \\
0.90)\end{array}$ & 0.001 & $\begin{array}{c}0.048(0.019 \text { to }- \\
0.076)\end{array}$ & 0.002 \\
\hline $\begin{array}{l}\text { Number of healthy } \\
\text { houses (\%) }\end{array}$ & $\begin{array}{c}-4.28(-7.96 \text { to }- \\
0.615)\end{array}$ & 0.024 & $\begin{array}{c}-3.62(-6.275 \text { to }- \\
0.956)\end{array}$ & 0.009 \\
\hline $\begin{array}{l}\text { Location of houses in } \\
\text { slums }\end{array}$ & $11.94(4.32-19.57)$ & 0.003 & $5.48(-1.210$ to 12.176$)$ & 0.104 \\
\hline
\end{tabular}

$\mathrm{R}^{2}=0.565$ \# \# V Variables did not meet the requirements of $\mathrm{p}<0.05$ to be included in the multiple liner regression model.

\begin{tabular}{l}
\hline DISCUSSION \\
This study analyzed the relationship \\
between the role of the National Health \\
System (number of health centers, number \\
of doctors and nurses and municipality \\
budget for pulmonary tuberculosis control \\
in each province) and risk factors for TB \\
(HIV infection, healthy houses and slums) \\
with the pulmonary TB prevalence in 33 \\
provinces in Indonesia.
\end{tabular}

In this study, the number of health centers in each province is varied. Provinces with the highest ratio of health centers are West Papua of 5.07 per 30,000 population, while Banten has the lowest ratio of 0.60 per 30,000 population (Kementerian Kesehatan Republik Indo- nesia, 2013b). Based on the results of this study the ratio of health centers in each province has no effect on the prevalence of pulmonary tuberculosis although in the last 5 years there was an increase in numbers (Kementerian Kesehatan Republik Indonesia, 2016). It was because an increase in the number of health center did not directly describe the fulfillment of basic health care needs in an area and community accessibility to basic health services. The situation was closely related to the number of population and the extent of the working area. Some provinces had relatively little population but the working area was large. A wide working area with fewer population, had a greater number of health centers 
Journal of Epidemiology and Public Health (2016), 1(3): 164-174

https://doi.org/10.26911/jepublichealth.2016.01.03.03

compared to provinces with smaller working areas but more population.

Based on the number of doctors and nurses in each province, this study showed insignificant results between the number of doctors and nurses with the prevalence of pulmonary $\mathrm{TB}$, although according to Ministry of Health data the ratio of health workers, per 100,000 population for doctors, specialists, nurses, and midwives had increased in the period 2004-2008. However, this amount was relatively low compared to the Philippines and Malaysia. This could happen because the distribution of doctors was more centered in Java-Bali island and in urban areas, so there were areas with few doctors but there were many nurses while in other areas there are many doctors but fewer nurses.

The deployment of the number of doctors and nurses that were not balanced with the number of population, causing pulmonary TB control efforts were only limited to treatment or curative. The preventive promotive activity had not been carried out optimally. Due to limitations, health workers only recorded and treated TB patients with less attention to preventive efforts against their families and environment. This was in accordance with a study conducted by Suharyo (2013) which stated that the implementation of efforts to prevent pulmonary $\mathrm{TB}$ transmission was still very lacking. Therefore, the roles and responsibilities of health workers are indispensable in helping pulmonary tuberculosis patients to take actions that do not increase the likelihood of pulmonary TB spread to others (Mansur et al., 2016).

Health workers can provide education, supervision and also providing motivation. Based on the results of study observations by Helper et al., patients with pulmonary TB have the habit of not covering their mouths when coughing. This certainly can cause TB transmission to healthy people around them (Kementerian Kesehatan Republik Indonesia, 2014).

Khadijah et al., (2015) states that health workers in the health center responsible for the prevention of pulmonary $\mathrm{TB}$ are doctors. Pulmonary TB officers are only in charge of conducting case discovery, screening into villages, making slide fixations, delivering phlegm slides to microscopic referral health center (MRH), and conducting counseling. The doctor is responsible for diagnosing pulmonary $\mathrm{TB}$ patients. Health workers involved and responsible for pulmonary $\mathrm{TB}$ control in the Puskesmas should not only be pulmonary TB officers, but there are other supports such as other health workers (Budiman, 2012).

Pulmonary TB officers would not be able to deal with pulmonary TB problems without collaboration with other health workers, especially in an effort to find TB cases. For this reason the balanced number and distribution of health workers still had to be pursued.

Promotive and preventive efforts needed to be improved in their application to achieve success in pulmonary TB control and HIV co-infection. The efforts that could be done were providing training for health workers about TB, counseling about TB to supervisor taking medicine for TB patients and the community, conducting socialization through mass media and electronics to improve Public Health Nursing, giving awards to patients who recover from $\mathrm{TB}$ and providing incentives to officers. The other important thing in the preventive promotive efforts is to increase health care facilities that provide Care, Support and Treatment (CST), do cases collection and promote partnerships with NGOs and sectors (Directorate of Special Education for Development and Basic Education 
Services, 2009), so that pulmonary TB control and HIV can be run from any direction.

The results show that district/municipality budget affects the prevalence of pulmonary TB in each province. Sources of funding for TB programs include the government budget in the form of the national budget and district/municipality budget. The allocation of funding from the district/municipality budget is used to finance the implementation of TB program activities at the provincial and district/city levels, to discuss the main tasks and functions of the local government (WHO, 2011).

In the study of Khadijah et al., In Lalang Medan Health Center, it was mentioned that in implementing pulmonary TB control programs, the Health Center used health operational fund of public health office. The funds obtained by the health center were only for the cost of delivering slides to Microscopic Referral Health Center (MRH), counseling, and doing treatment, but not specifically for screening cases by visiting the community directly.

Funds from the government, especially the district/municipality budget for the pulmonary TB program are still minimal and inadequate. It is because the funds obtained are only for independent implementing health center meetings, increased diagnosis, and supervision, as well as a reduction in donor funds. Meanwhile, funds obtained from the Global Fund donors are also decreasing (Budiman, 2012). This study was in line with Budiman's (2012) study, stated that the implementation of tuberculosis control from the funding aspect with the most funding sources came from the Global Fund. The contribution of donor funds by the Global Fund is very significant towards the running of TB control activities in Padang City. While the source of funds from the government is very minimal. This is because the local government considers the funds for TB control program activities are big enough (Corbett EL, Watts CJ, Walker N, 2003).

HIV co-infection with pulmonary TB prevalence in this study showed significant results. HIV/AIDS and pulmonary TB, currently a global health problem. Pulmonary TB is the most common opportunistic infection in people with HIV/AIDS in the world. Mycobacterium tuberculosis is an infectious agent that can appear as a reactivation of latent infection in patients with decreased immune function (immunocompromised) or as primary infection after transmission from person to person at various stages of HIV.

Tuberculosis is the cause of death in $13 \%$ of people with HIV infection (Fatimah, 2008). HIV/TB coinfected patients have a high risk of developing active $\mathrm{TB}$, either from reactivation of latent infection or from the progression of new infections. The risk of developing TB in HIV patients increases by $5-15 \%$ annually. This risk is caused by reactivation of the latent infection. These factors are caused by socio-economic factors that are closely related to unhealthy behavior, such as smoking or consuming alcohol. In addition, there are host factors such as a history of anemia.

The HIV/TB epidemic will have negative impacts on AIDS and TB programs. These impacts include increasing the burden of cases of active TB caused by HIV, increasing HIV morbidity and mortality in TB patients, making higher dropout rates and lower cure rates, increasing adverse reactions to drugs during TB treatment, and increasing the risk of $\mathrm{TB}$ transmission (including 
Journal of Epidemiology and Public Health (2016), 1(3): 164-174

https://doi.org/10.26911/jepublichealth.2016.01.03.03

nosocomial transmission) (Harmayanti and Konsukartha, 2007).

Often people with TB are detected as having HIV if they have TB first, while people with HIV can easily get TB if they interact with people who have positive TB. To control the transmission of TB germs can be done early detection of patients with suspect TB. Often, people with $\mathrm{TB}$ are detected as having HIV if they have TB first. While PLWHA can be easily affected by TB, when interacting with people affected by positive TB. To control the transmission of TB germs, early detection of patients with suspect TB can be done.

Early preventive measures, in addition to facilitating treatment, also suppress TB germs to become resistant which is certainly dangerous if allied with HIV. Whereas to prevent the spread of HIV can also be through early detection and discovery of patients through screening for HIV and AIDS. Screening can be carried out on blood donor results, monitoring at risk groups such as sexually transmitted diseases (STDs), drug users through needles and in low-risk groups such as housewives. So, it is necessary for someone who has been infected with HIV positive or PLWHA to conduct early examinations and treatment so that they are not easily infected with TB germs (Pudjiastuti, 2002).

The effect of the number of healthy houses on the prevalence of pulmonary TB, showed significant results. When the number of healthy houses increase, the prevalence of pulmonary TB decreases. Environmental factors (density, house floor, ventilation, etc.) are risk factors that contribute to pulmonary TB disease. The physical environment of the house also contributes to the health status of its inhabitants. A healthy house is a house that has good air conditioning, adequate lighting, and suitable temperature and humidity. In this case, the quality of building materials is also influential.

The results of Azhar's (2013) study showed that more pulmonary TB patients lived in houses with bamboo plaited ceilings, or other than concrete and tile in Banten and North Sulawesi provinces. The floor was generally made of nonimpermeable material such as broken plastering cement, boards/bamboo and soil. Poor indoor air quality was indicated by the amount of fuels used such as wood and kerosene in North Sulawesi, as well as the number of family members who smoke in households, in DKI Jakarta, Banten and North Sulawesi.

Floor condition has a significant relation with the incidence of pulmonary TB. Houses that have broken cement floors/plastered /ground floor were at risk of 1,731 times greater than the incidence of pulmonary $\mathrm{TB}$ compared to houses with ceramic, tile or marble floors (Kumar, et al., 2003). The results of Fatimah's study (2008) showed that there is a relationship between the incidence of pulmonary TB with humidity, type of wall, ventilation and lighting.

According to the results of the study, the decline in the number of houses in the slum environment would reduce the prevalence of pulmonary TB. The slum environment could be a factor in the incidence of pulmonary TB. This is consistent with the study of Fauziah (2014) that there were $23.4 \%$ of houses in slums in Petamburan, Jakarta, that its residents suffer from respiratory health problems, of which $10.3 \%$ are people with pulmonary TB. The slum environment is identical to dirty air. The house in the neighborhood is crowded and there is no open space, so that less sunlight enters the house. The condition of the house is moist and dusty, so the 
occupants have a high risk of being infected with TB germs.

Pulmonary tuberculosis bacteria would grow well and could infect the occupants of the house, if less sunlight came into the house and the house became moist. These results were consistent with previous studies that showed there was a relation between ventilation and the incidence of respiratory health problems (Riskedes, 2013). The density of house occupancy was closely related to the prevalence of pulmonary TB. Resettlement relocation programs from slum environments were expected to reduce the risk of pulmonary TB prevalence. It was necessary to improve the physical condition of the house to become a healthy home according to the requirements of the Ministry of Health. A habitable environment became a program that must get serious attention from the stakeholders, in this case the government through the relevant institutions. Active role and public awareness were also important efforts in the context of the prevention of pulmonary TB and HIV coinfection.

The results of this study can be concluded that the highest prevalence of pulmonary $\mathrm{TB}$ in Indonesia is in the provinces of West Java and Special Capital Region of Jakarta. The lowest pulmonary TB prevalence is in the provinces of Bali, Lampung and Riau. The difference in pulmonary tuberculosis prevalence in 33 provinces in Indonesia is caused by the existence of conditions in the allocation of the municipality budget in the health sector, the number of new cases of HIV, the number of healthy houses and the slum house environment.

The number of new cases of HIV, healthy houses and homes in the slum environment have a statistically significant relationship with the prevalence of pulmo- nary TB. The number of health centers, doctors and nurses have a relationship that was not statistically significant.

It is hoped that the local government will increase its commitment in allocating budget for the prevention of pulmonary TB. The number of doctors and nurses involved in pulmonary TB control needs to be improved through collaboration with other health workers. Community empowerment is needed through the formation of $\mathrm{TB}$ cadres and improved implementation of a healthy house program.

\begin{tabular}{l}
\hline REFERENCE \\
\hline Aditama TY (2008). Pedoman Nasional \\
Penanggulangan Tuberkulosis. Edisi \\
ke-2. Departemen Kesehatan Repu- \\
blik Indonesia: Jakarta. \\
Azhar KH, Perwitasari D. Pusat Teknologi \\
Intervensi Kesehatan Masyarakat, \\
Balitbang Kesehatan, Kemenkes RI Jl. \\
Percetakan Negara No.29, Jakarta, \\
Indonesia.
\end{tabular}

Budiman H (2012). Analisis Pelaksanaan Advokasi, Komunikasi dan Mobilisasi Sosialdalam Pengendalian Tuberkulosis di Dinas Kesehatan Kota Padang Tahun 2011. Jurnal. Prodi IKM Pascsarjana Universitas Andalas. Padang.

Corbett EL, Watts CJ, Walker N (2003). The Growing Burden to Tuberculosis Global Trends and Interactions with the HIV Epidemic. Arch Intern Med.

Departemen Kesehatan RI (2011). Strategi Nasional Pengendalian TB di Indonesia 2010-2014. Direktorat Jenderal Pengendalian Penyakit Dan Penyehatan Lingkungan: Jakarta.

(2008). Pedoman Penanggulangan Nasional TBC. Departemen Kesehatan Republik Indonesia: Jakarta.

Direktorat Pembinaan Pendidikan Khusus dan Layanan Khusus Pendidikan 
Journal of Epidemiology and Public Health (2016), 1(3): 164-174

https://doi.org/10.26911/jepublichealth.2016.01.03.03

Dasar (PPK-LK Dikdas) (2009). Infeksi HIV SeringDisertai Tuberkulosis. Jakarta. Diakses dari http:// www.pkplkplb.org/index2.php?optio $\mathrm{n}=$ com_content\&do_pdf $=1 \& \mathrm{id}=751$

Fatimah S (2008). Faktor Kesehatan Lingkungan Rumah yang Berhubungan dengan Kejadian TB Paru di Kab. Cilacap tahun 2008 . Tesis. Program Pasca Sarjana Universitas Diponegoro. Semarang.

Harmayani KD, Konsukartha IGM (2007). Pencemaran Air Tanah Akibat Pembuangan Limbah Domestik di Lingkungan Kumuh: Studi KasusBanjir Ubung Sari, Kelurahan Ubung. Jurnal Pemukiman Natah.

Kementerian Kesehatan Republik Indonesia (2010). Pedoman Manajerial Pelayanan Tuberkolosis Dengan Strategi DOTS di Rumah Sakit: Jakarta.

(2013a). Laporan Nasional Riset Kesehatan Dasar. Pusat Penelitian Pengembangan Kesehatan: Jakarta. (2013b). Riset Kesehatan Dasar 2013. Badan Penelitian dan Pengembangan Kesehatan: Jakarta. (2014). Pedoman Nasional PenanggulanganTuberkulosis. Departemen Kesehatan Republik Indonesia. Edisi 2, Cetakan I: Jakarta.

(2016). Profil Kesehatan Indonesia Tahun 2015. Kementerian Kesehatan RI. Sekretariat Jenderal. Jakarta.

Kumar V, Cotran RS, Robbins SL (2003). Basic Pathology. 7th Ed. Saunders. New York.Helper, Sahat PM (2010). Faktor-faktor Yang Mempengaruhi Kejadian TB Paru Dan Upaya Penanggulangan. Jurnal Ekologi Kesehatan, 9(4): 1340-1346.

Mansur M, Khadijah S, Rusmalawaty (2016). Analisis Penatalaksanaan Pro- gram Penanggulangan Tuberkulosis Paru Dengan Strategi DOTS di Puskesmas Desa Lalang Kecamatan Medan Sunggal Tahun 2015. Departemen Administrasi dan Kebijakan Kesehatan FKM USU Sumatera Utara, Medan, Indonesia.

Pudjiastuti W (2002). Strategi Mengatasi Masalah Kesehatan dan Lingkungan Hidup di Pemukiman Kumuh lewat Program Pemasaran Sosial. Makara, Sosial Humaniora.

Riskesdas (2013). Badan Penelitian dan Pengembangan Kesehatan Kementerian Kesehatan 2013.

Suharyo (2013). Determinasi Penyakit Tuberkulosis di Daerah Pedesaan. Program Studi Kesehatan Masyarakat, Fakultas Kesehatan, Universitas Dian Nuswantoro, Indonesia. Jurnal Kesehatan Masyarakat. Di akses dari http://journal.unnes.ac.id/ nju/index.php/kemas

Suriadi (2001). Tuberkulosis Paru. Agung Seto: Jakarta.

WHO (2014). Global Tuberculosis Report 2014. WHO Press: Switzerland. (2015). Global Tuberculosis Report 2015. WHO Press: Switzerland. (2010a). TB A Clinical Manual for South East Asia: Geneva.

(2010b). Monitoring the Building Block of Health Systems: A Handbook of Indicators and Their Measurement Strategies. World Health Orgnization: Genewa.

(2011). Global Tuberculosis Control. WHO: Report 2011. Geneva. 